\title{
A functionally orthogonal ligand-receptor pair created by targeting the allosteric mechanism of the thyroid hormone receptor
}

\author{
A. Quamrul Hassan and John T. Koh ${ }^{*}$ \\ Department of Chemistry and Biochemistry, University of Delaware, Newark, Delaware 19716
}

\begin{abstract}
Nuclear receptors are ligand-dependent transcription factors that are of interest as potential tools to artificially regulate gene expression. Ligand binding induces a conformational change involving helix-12 which forms part of the dimerization interface used to bind transcriptional co-activators. When triiodothyronine (T3) binds the thyroid hormone receptor (TR) it indirectly contacts helix-12 through intermediary residues His(435) and Phe(451) termed a His-Phe switch. The mutant TR $\beta$ (H435A) is non-responsive to physiological concentrations of $\mathrm{T} 3$ but can be activated by the synthetic hormone analog $\mathrm{QH} 2$ which potently activates His $435 \rightarrow$ Ala mutant at concentrations that do not activate the wild-type receptors TR $\alpha$ and TR $\beta$. QH2 does not show antagonist behavior with the wildtype TRs. QH2's functionally orthogonal behavior with TR $\beta(H 435 \mathrm{~A})$ is preserved on the three consensus thyroid hormone response elements.
\end{abstract}

Nuclear hormone receptors (NHRs) are ligand-dependent transcription factors that regulate gene transcription in response to small molecule hormones. NHRs directly bind DNA sequences in hormone responsive genes and activate transcription in response to hormone. NHRs that have been engineered to uniquely respond to synthetic ligands are of interest as artificial gene regulatory systems. Several approaches have been used to engineer NHRs including screening molecular libraries for ligands that match non-functional receptor mutants or by selecting libraries of receptor mutations that impart response to otherwise inactive ligand analogs. ${ }^{1-5}$ The highly flexible nature of NHR ligand binding domains make it difficult to construct highly specific ligand-receptor pairs as mutant receptors often retain significant activity towards their natural hormones and ligand analogs often have activities with endogenous receptors. Here we describe a highly selective, "functionally-orthogonal," ligandthyroid hormone receptor (TR)-ligand pair generated by targeting receptor residues directly involved in the receptors ligand-dependent transactivation allosterism. The site of receptor modification, identified by examining naturally occurring mutations to TR associated with genetic disease, should provide a general strategy for generating highly selective ligandreceptor pairs from NHRs.

NHRs are composed of two fundamental functional domains; a DNA binding domain that uniquely targets an NHR to a specific subset of hormone-responsive genes and a ligand-binding domain which selectively binds hormone and activates gene transcription. Upon binding hormone, the NHR ligand-binding domain undergoes a conformational change that leads to the release of co-repressor proteins and the recruitment of transcriptional co-activators. ${ }^{6-8}$ Helix-12 of the ligand-binding domain plays a central role in controlling the ligand-induced receptor allosterism as it has been observed to undergo a substantial conformational change 
on ligand binding and to form a part of the receptor/co-activator interface. The proper positioning of helix-12 is required to create a proper dimerization interface for "LXXLL" NRbox sequences of transcriptional co-activators (Scheme 1A). The co-crystal structures of NHR ligand-binding domains with antagonists suggest that many antagonists block transcriptional activation by preventing helix-12 from adopting its active agonist conformation. 9,10

Although the conformation of helix-12 is highly dependent on the structure of the bound ligand, surprisingly, most of the known NHR ligand-binding domain structures indicate that the ligand does not directly contact helix-12 but rather the ligand interacts with helix-12 through intermediary residues that bridge between the ligand and helix-2. For example, in the T3TR $\beta$ co-crystal structure, the 4'-hydroxyl of T3 hydrogen bonds to His 435 that in turn forms favorable interactions (either pi-pi or edge-face interactions) with Phe 459 a critical residue on helix-12 (Scheme 1B). This general motif was first recognized in LXR involving His435 and Trp457, and was termed a His-Trp switch or in the case of TR, a His-Phe switch. ${ }^{11}$ A similar His-Phe switch is found in TR $\alpha$ and in VDR involving His397 and Phe422 (Figure 1). ${ }^{12,13}$ Mutations to these residues that are directly involved in the mechanism of ligand-induced allosterism can have a dramatic effect on hormone responsiveness to these receptors. For example, mutation to the His member of His-Trp/His-Phe switches as in LXR $\beta(H 435 \mathrm{~A})$, LXR $\alpha(\mathrm{H} 421 \mathrm{~A})$ and VDR(H305Q) or mutation to the Trp/Phe residues as in LXR $\alpha(\mathrm{W} 443 \mathrm{~F})$ and TR $\beta(\mathrm{F} 459 \mathrm{C}), \operatorname{TR} \beta(\mathrm{F} 459 \mathrm{~A})$ cause inactivity or show severely reduced activity compared to wild-type. ${ }^{11,14-16}$ The rickets-associated mutant VDR(H305Q) is of particular interest because the Gln residue retains the potential to hydrogen bond to the ligand. Although the natural ligand, 1,25-dihydroxy vitamin D3, binds VDR(H305Q) with near wild-type affinity in vitro, it is substantially less potent (80-fold less potent) in cellular transcription assays indicating that the transduction mechanism is specifically impaired. ${ }^{16}$

Several groups have developed analog-selective forms of hormone receptors as ligandinducible regulators of gene expression by screening ligand libraries to match mutant receptors or by applying selection/directed evolution methods to identify receptors that respond to otherwise inactive ligand analogs. $2,4,5,18,19$ One of the challenges associated with generating orthogonal ligand-receptor pairs from NHRs is finding mutations that efficiently prevent activation by the endogenous hormone without otherwise compromising the receptor's structure or intrinsic ability to activate gene transcription. A few groups have used genetic selections in yeast to identify mutant receptors that selectively respond to synthetic ligands, however, the ligand's selectivity for the mutant versus the wild-type receptor can change substantially when these ligand-receptor pairs are transferred to mammalian cell lines. ${ }^{1,4,5} \mathrm{In}$ some cases, receptors selected for their ability to respond to synthetic ligands, may also retain significant activity for their natural ligands. ${ }^{4}$

For consideration as artificial transcriptional regulators, engineered receptors should not be responsive to physiological concentrations of the natural hormone but respond to concentrations of a synthetic ligand analog that does not activate wild-type (or other endogenous) receptors. We have termed ligand-receptor pairs that match this practical definition for functioning independent of the endogenous hormone-receptor pair as "functionally orthogonal."2,20 Though of potential academic interest, the change in the receptor's selectivity for the synthetic versus natural ligand (i.e. the receptor's "ligand selectivity") will have little practical importance if the concentrations of synthetic ligand needed to activate the engineered receptors also activate endogenous receptors. Provided that a modified receptor is no longer responsive to endogenous concentrations of the natural ligand, the synthetic ligand's receptor selectivity, defined as $\mathrm{EC}_{50}($ mutant $) / \mathrm{EC}_{50}(\mathrm{wt})$ for a given ligand represents a practical measurement of selectivity of a system. By this criterion ligand-receptor pairs developed by directed evolution strategies do not show better receptor selectivity than 
the best systems developed by rational design. ${ }^{2}$ This suggests that judicious choice of the site of receptor modification is necessary for any ligand-receptor engineering strategy.

As part of our program to generate small molecules that rescue function to mutant NHRs associated with human genetic diseases, ${ }^{21-24}$ we have developed thyroid hormone receptor analogs that complement mutant forms of TR $\beta$ associated with the genetic disease RTH (resistance to thyroid hormone). RTH is characterized by a hyposensitivity to thyroid hormone, triiodothyronine (T3), in peripheral tissues. The vast majority of RTH-associated mutations show dominant-negative inheritance indicating that the presence of one mutant copy of the receptor is able to compete with, and directly interfere with the function of wild-type copies of the receptor through the formation of inactive receptor dimers. 8,25 The dominant negative activity of RTH-associated TR mutants imply that these receptors have a relatively stable structure that can bind DNA and form receptor dimers but are functionally impaired in their ability to bind ligand and recruit co-activators.

Surprisingly, many TR $\beta$ mutants associated with RTH are only mildly less responsive to T3 than wild-type $\operatorname{TR} \beta(\operatorname{TR} \beta(w t))$. For example, some of the most common RTH-associated mutants, TR $\beta(\mathrm{R} 320 \mathrm{C}), \mathrm{TR} \beta(\mathrm{R} 320 \mathrm{H})$ and TR $\beta(\mathrm{M} 310 \mathrm{~T})$, under investigation in our laboratory show less than a 10-fold reduction in responsiveness to T3 compared to wild-type, TR $\beta(w t)$. $21,22,26$ Evidently, even relatively modest changes in hormone responsiveness are sufficient to upset the normal balance of peripheral tissue responsiveness and hormone synthesis needed to cause RTH.

In general, nuclear receptors appear to accommodate a wide range of mutations without gross impairment of receptor function. Even when ligand potency is significantly reduced by receptor mutations, ligands often show full efficacy though at higher ligand concentrations. ${ }^{27}$ Similarly, NHRs can often accommodate a range of ligand structures that would initially appear to cause steric clashes with receptor side-chains. ${ }^{28,29}$ In contrast, some RTH-associated mutations are known to have dramatic effects on receptor function. Mutations to His435, His435 $\rightarrow$ Tyr, His $435 \rightarrow$ Leu and His $435 \rightarrow$ Gln, have been shown to have large effects on hormone responsiveness and have been identified in RTH patients as well as in TSH secreting pituitary adenoma (TSHoma) tumors. $30,31 \mathrm{TR} \beta(\mathrm{H} 435 \mathrm{Y})$ has strongly refractory response to T3 and is 230-times less responsive towards T3 than TR $\beta(w t)$ TR $\beta(\mathrm{H} 435 \mathrm{~L})$ is completely devoid of cellular activity within experimentally accessible concentrations of T3. ${ }^{30}$ Examination of the T3-TR $\beta(w t)$ co-crystal structure, ${ }^{32}$ does not suggest any obvious structural perturbations associated with these mutations. Rather, mutations to His435, a part of TR's His-Phe switch, may disrupt the normal molecular transduction of the ligand-binding signal to helix-12. Similar magnitude effects were observed with mutations to Phe 459 which is the interacting partner of His435 located on helix-12. ${ }^{14,15}$ The low responsiveness of the mutations at His 435 prompted us to exploit this critical transducer residue to create highly selective ligand-receptor pairs from TRß.

We have generated the His $435 \rightarrow$ Ala mutation in TR $\beta$ (pSG5hTR $\beta$ ) using oligonucleotide directed site-specific mutagenesis and evaluated its activity in transiently transfected HEK293 cells that were cotransfected with pSG5hTR $\beta(\mathrm{H} 435 \mathrm{~A})$, the hormone responsive promoter DR4-Luc ${ }^{+}$and pRLbasic, a renilla luciferase control. The alanine substitution was selected as a cavity forming mutation that would maintain a high helical propensity at position 435 , which is centrally located in helix-11. Reporter gene assays conducted with this mutation demonstrate that $\operatorname{TR} \beta(\mathrm{H} 435 \mathrm{~A})$ is 769 -fold less responsive to $\mathrm{T} 3\left(\mathrm{EC}_{50}=392 \pm 84 \mathrm{nM}\right)$, than $\mathrm{TR} \beta(\mathrm{wt})$ $\left(\mathrm{EC}_{50}=0.51 \pm 0.05 \mathrm{nM}\right)$. The synthetic halogen-free thyromimic GC-1 is more than 2380 -fold less potent with $\mathrm{TR} \beta(\mathrm{H} 435 \mathrm{~A})\left(\mathrm{EC}_{50}>5000 \mathrm{nM}\right)$ than with $\mathrm{TR} \beta(\mathrm{wt})\left(\mathrm{EC}_{50}=2.1 \mathrm{nM}\right)$ (Figure 2). Although the TR $\beta(H 435 \mathrm{~A})$ is still responsive to extremely high concentrations of $\mathrm{T} 3$, the mutant is no longer responsive to physiological concentrations of T3, which are generally well 
below $2 \mathrm{nM}$ (total T3 $=2 \mathrm{nM}$; free T3 3-8 pM) ${ }^{6}$ suggesting that TR $\beta(\mathrm{H} 435 \mathrm{~A})$ is nonresponsive to physiological concentrations of $\mathrm{T} 3$.

We envisioned that the His-Phe switch found in TR $\beta(w t)$ which uses both hydrogen bonding and edge-pi aromatic interactions could be replaced by an appropriate hydrophobic cluster (Scheme 1C). Based on a site-model generated from an appropriately modified TR $\beta / T 3$ cocrystal structure, we designed two series of potential, mutant-selective analogs of the halogenfree thyromimetic GC1. The general synthetic strategy is based on the synthesis of Scanlan et al. ${ }^{33,34}$ Three 4'-O-alkyl substituted ethers of GC-1, QH1, QH2 and QH3 were synthesized from the corresponding 2-isopropylphenol ethers (Scheme 2).

Similarly, 4'-alkyl substituted analogs of GC-1 were synthesized via Kumada coupling of the intermediate aryl triflate $\underline{\mathbf{7}}$ (Scheme 3). While the synthesis of QH4, QH5 and QH7 by this route was straight-forward, Kumada coupling with the more stericly demanding isopropyl grignard afforded $8 \mathrm{c}$ which contained the proteo-analog $8 \mathrm{e}$ as an inseparable impurity. The "benzene" analog QH9 was synthesized independently by another route and was found to be inactive in cell based assays with TR $\beta(\mathrm{H} 3435 \mathrm{~A})$ (Scheme 3). Therefore, QH6 was synthesized and evaluated as an 85\% mixture of QH6 and QH9.

The analogs QH1-QH7 were evaluated in cell based reporter gene assays. All of the analogs show some activity below one micromolar with the mutant TR $\beta(\mathrm{H} 435 \mathrm{~A})$, however, only QH2, the $O$-ethyl ether of $\mathrm{GC} 1$, has low nanomolar activity $\left(\mathrm{EC}_{50}=6.4 \pm 0.57\right)$ with the Ala mutation (Figure 3). QH2 is 61-fold more potent than $\mathrm{T} 3$ and 778-fold more potent than the parent analog $\mathrm{GC} 1$ with the mutant TR $\beta(\mathrm{H} 435 \mathrm{~A})$. The structure appears to be quite sensitive to the exact size of the alkoxy subtituent at the 4' position as the methoxy substituted analog $\mathrm{QH} 1\left(\mathrm{EC}_{50}=55\right.$ $\mathrm{nM}$ ) is 9-times less potent with half the efficacy (45\%). The propoxy substituted analog QH3 $\left(\mathrm{EC}_{50}=130 \mathrm{nM}\right)$ is also significantly less active than $\mathrm{QH} 2$. Interestingly, the isosteric 4'-propyl analog QH5 is not very potent suggesting that the ether oxygen may still be important for high affinity binding to the mutant. The propyl and isopropyl substituted analogs, QH5 and QH6, are very poor agonists for TR $\beta(\mathrm{H} 435 \mathrm{~A})$, however, the isobutyl analog, $\mathrm{QH} 7\left(\mathrm{EC}_{50}=123 \mathrm{nM}\right)$, is slightly more active.

Our ability to rescue the His $435 \rightarrow$ Ala mutant of TR $\beta$ prompted us to examine if these same ligands may be able to rescue related RTH mutants, TR $\beta(\mathrm{H} 435 \mathrm{~L}), \mathrm{TR} \beta(\mathrm{H} 435 \mathrm{Y})$. Cell based reporter gene assays indicate that QH1 thru QH7 were devoid of activity below $5 \mathrm{uM}$ (data not shown). The lack of activity observed with any of our ligands with these related His-tohydrophobic mutations further suggest that successful rescue at this position requires a precise match and size, shape and functionality.

The mutant TR $\beta(\mathrm{H} 435 \mathrm{~A})$ is not responsive to physiological concentrations of T3. As a potential tool for independently regulating gene expression, it is important to further demonstrate that the concentrations of $\mathrm{QH} 2$ used to fully activate the mutant TR $\beta(\mathrm{H} 435 \mathrm{~A})$ do not activate either of the two known TR subtypes; TR $\beta(w t)$ or TR $\alpha(w t)$. Cell based reporter gene assays show that $\mathrm{QH} 2$ is a weak agonist for both $\mathrm{TR} \alpha(\mathrm{wt})\left(\mathrm{EC}_{50}=737 \mathrm{nM}\right)$ and $\mathrm{TR} \beta(\mathrm{wt})\left(\mathrm{EC}_{50}=341 \mathrm{nM}\right)$. $\mathrm{QH} 2$ is therefore 53-fold selective for the mutant TR $\beta(\mathrm{H} 435 \mathrm{~A})$ over the TR $\beta(\mathrm{wt})$ and 115times more potent than $\mathrm{hTR} \alpha(\mathrm{wt})$. Concentrations of $\mathrm{QH} 2$ that almost fully activate with $\operatorname{TR} \beta(\mathrm{H} 435 \mathrm{~A})$ do not significantly activate the endogenous receptor TR $\beta(\mathrm{wt})$ or TR $\alpha(\mathrm{wt})$ (Figure 4a, Table 1).

Thyroid hormone receptor can act on hormone responsive genes bearing several consensus types of thyroid hormone response elements in their promoters. ${ }^{8}$ The DR4 promoter is the most common thyroid hormone response element (TRE), however, it is also important to evaluate the potency, efficacy and selectivity of our compounds on the other common TREs, PAL and F2. Reporter gene assays conducted using F2-luc and PAL-luc promoters show that 
QH2 retains mutant selectivity, potency and efficacy on genes controlled by these common TREs. The actions of QH2 on the TR $\beta(H 435 \mathrm{~A})$ mutant were also found to be functionally orthogonal on two other common thyroid hormone response elements, F2 and PAL (Figure 4B and $4 \mathrm{C}$ ). Furthermore, $\mathrm{QH} 2$ does not compete with T3 in TR $\beta(\mathrm{wt})$ demonstrating that $\mathrm{QH} 2$ is not an antagonist and only serves as a potent and selective agonist for the engineered mutant (Figure 5, Table 2).

Compared to other known mutations in the TR $\beta$ ligand binding pocket, mutations to His435 which disrupt the receptors "His-Phe switch" represent a hypersensitive region of the ligand binding pocket that can be effectively manipulated to generate highly selective ligand-receptor pairs. In this example, receptor function is greatly impaired (769-fold) by His $435 \rightarrow \mathrm{Ala}$ mutation, which is almost completely rescued by the synthetic ligand $\mathrm{QH} 2$ which is more than 777-fold more potent than the parent analog GC-1. Significantly, though a similar motif is used to relay ligand binding to helix-12 in several other nuclear receptors, the use of hydrogen bonding and edge-pi aromatic interactions to act as transducers of ligand binding to AF-2 domain is not essential and can be replaced with a hydrophobic cluster. Subtle structural modifications of the ligand at this position lead to large changes in ligand potencies and efficacies.

His 435-Phe459 switch of TR $\beta$ is only part of a complex network of molecular interactions involved in ligand-dependent switching of TR $\beta$ to its active conformation. Therefore, even though T3 is 769-fold less potent in TR $\beta(H 435 \mathrm{~A})$ than TR $\beta(w t)$, it is still a full agonist in the mutant. It is important to recognize that ligand binding and activity are energetically coupled as has been shown that the presence of co-activators can affect ligand off-rates 35 and observed cellular potencies $\left(\mathrm{EC}_{50}\right.$ 's).36 Here we target residues involved in transactivation but are in principle effecting binding activity as well. The low affinity of T3 for TR $\beta(\mathrm{H} 435 \mathrm{~A})$ made determination of QH2's binding affinity by standard radio-ligand displacement assays intractable. His 435 plays a role in both ligand binding and transactivation function and QH2 is a very weak agonist towards $\operatorname{TR} \beta(w t)$ and does not show antagonist activity with $\operatorname{TR} \beta(w t)$.

The selectivites observed with QH2 are not as good as the best analogs identified through multiple rounds of selection which have reported selectivites of 10-300 fold or the best systems developed by design (up to 400-fold). For example, Schwimmer et al., identified a RXR mutant that was 300-times more responsive to the synthetic ligand LG335 than wild-type RXR, however the selected receptor retains substantial activity with the natural ligand 9-cis-retinoic acid. ${ }^{37}$ Zhao et al. reported that in HEC-1 cells, dihydroxybenzil (DHB) had a receptor selectivity of 178-fold with a modified estrogen receptor (ER) mutant identified through multiple rounds of selection. This mutant identified through selection also exploited residues at the interface between helix-11 and helix-12. Interestingly, this same ligand exhibited only 8 -fold receptor selectivity between this same mutant and wild-type in the original yeast strain from which it was identified. The 53-fold receptor selectivity of QH2 for TR $\beta(H 435 \mathrm{~A})$ is above the median selectivity reported for other single point mutation rescues reported in the literature.

Mutant-selective ligands (or substrates) for engineered proteins are an important chemical biological tool for the study of cellular function. The design of functionally orthogonal ligandreceptor pairs from flexible proteins such as NHRs presents a unique challenge in molecular design. Steric-based strategies or "bump-and-hole" engineered ligand-receptor pairs often fail to provide receptors that no longer respond to endogenous ligands or ligands that do not also activate endogenous receptors. $^{20}$

A variety of strategies have been used to develop mutant selective ligands including structurebased ligand design as well as selection/directed evolution strategies. Regardless of the design 
strategy, it is critical to judiciously select the site of receptor modification so as to effectively abolish response to the natural ligand without disrupting the intrinsic function of the receptor.

Here we describe a new ligand-receptor design strategy based on targeting critical residues involved in the ligand-dependent transactivation mechanism. Of note, His435 mutants of TR $\beta$ have been reported in human pituitary cancer as well as resistance to thyroid hormone, suggesting that similar ligand design strategies might someday be used to rescue receptor function associated with these important disease states.

\section{Supplementary Material}

Refer to Web version on PubMed Central for supplementary material.

\section{Acknowledgements}

We thank the National Institutes of Health for financial support of this work (NIH RO1DK54257). Q.H. was supported in part by a University of Delaware Competitive Graduate Fellowship.

\section{References}

1. Whelan J, Miller N. J Steroid Biochem Mol Biol 1996;58:3-12. [PubMed: 8809181]

2. Shi YH, Koh JT. J Am Chem Soc 2002;124:6921-6928. [PubMed: 12059215]

3. Tedesco R, Thomas JA, Katzenellenbogen BS, Katzenellenbogen JA. Chem Biol 2001;8:277-287. [PubMed: 11306352]

4. Schwimmer LJ, Rohatgi P, Azizi B, Seley KL, Doyle D. Proc Natl Acad Sci U S A 2004;101:1470714712. [PubMed: 15456909]

5. Chockalingam K, Chen ZL, Katzenellenbogen JA, Zhao HM. Proc Natl Acad Sci USA 2005;102:56915696. [PubMed: 15811944]

6. Hulbert AJ. Biol Rev 2000;75:519-631. [PubMed: 11117200]

7. Katzenellenbogen JA, Katzenellenbogen BS. Chem Biol 1996;3:87-94.

8. Yen PM. Physiol Rev 2001;81:1097-1142. [PubMed: 11427693]

9. Wurtz JM, Bourguet W, Renaud JP, Vivat V, Chambon P, Moras D, Gronemeyer H. Nat Struct Biol 1996;3:87-94. [PubMed: 8548460]

10. Weatherman RV, Fletterick RJ, Scanlan TS. Annu Rev Biochem 1999;68:559-581. [PubMed: 10872460]

11. Williams S, Bledsoe RK, Collins JL, Boggs S, Lambert MH, Miller AB, Moore J, McKee DD, Moore L, Nichols J, Parks D, Watson M, Wisely B, Willson TM. J Biol Chem 2003;278:27138-27143. [PubMed: 12736258]

12. Rochel N, Wurtz JM, Mitschler A, Klaholz B, Moras D. Mol Cell 2000;5:173-179. [PubMed: 10678179]

13. Wagner R, Apriletti JW, McGarth ME, West BL, Baxter JD, Fletterick RJ. Nature 1995;378:690697. [PubMed: 7501015]

14. Cheng SY, Ransom SC, Mcphie P, Bhat MK, Mixson AJ, Weintraub BD. Biochemistry 1994;33:4319-4326. [PubMed: 8155649]

15. Tone Y, Collingwood TN, Adams M, Chatterjee VK. J Biol Chem 1994;269:31157-31161. [PubMed: 7983057]

16. Gardezi SA, Nguyen C, Malloy PJ, Posner GH, Feldman D, Peleg S. J Biol Chem 2001;276:2914829156. [PubMed: 11369766]

17. Wilkinson JR, Towle HC. J Biol Chem 1997;272:23824-23832. [PubMed: 9295330]

18. Koh JT, Putnam M, Tomic-Canic M, McDaniel CM. J Am Chem Soc 1999;121:1984-1985.

19. Doyle DF, Braasch DA, Jackson LK, Weiss HE, Boehm MF, Mangelsdorf DJ, Corey DR. J Am Chem Soc 2001;123:11367-11371. [PubMed: 11707111]

20. Koh JT. Chemistry \& Biology 2002;9:17-23. [PubMed: 11841935]

21. Ye HF, O'Reilly KE, Koh JT. J Am Chem Soc 2001;123:1521-1522. [PubMed: 11456736] 
22. Shi Y, Ye H, Link KH, Putnam MC, Hubner I, Dowdel S, Koh JT. Biochem J 2005;44:4612-4626.

23. Swann SL, Bergh J, Farach-Carson MC, Ocasio CA, Koh JT. J Am Chem Soc 2002;124:1379513805. [PubMed: 12431109]

24. Swann SL, Bergh JJ, Farach-Carson MC, Koh JT. Org Lett 2002;4:3863-3866. [PubMed: 12599478]

25. Yen PM. Trends Endocrin Met 2003;14:327-333.

26. Furlanetto TW, Kopp P, Peccin S, Gu WX, Jameson JL. Mol Genet Metab 2000;71:520-526. [PubMed: 11073720]

27. Shi XB, Ma AH, Xia L, Kung HJ, White RWD. Cancer Res 2002;62:1496-1502. [PubMed: 11888926]

28. Katzenellenbogen JA, Muthyala R, Katzenellenbogen BS. Pure Appl Chem 2003;75:2397-2403.

29. Koh JT, Biggins JB. Curr Top Med Chem 2005;5:413-420. [PubMed: 15892683]

30. Nomura Y, Nagaya T, Tsukaguchi H, Takamatsu J, Seo H. Endocrinology 1996;137:4082-4086. [PubMed: 8828460]

31. Ando S, Sarlis NJ, Oldfield EH, Yen PM. J Clin Endocrinol Metab 2001;86:5572-5576. [PubMed: 11701737]

32. Wade CB, Robinson S, Shapiro RA, Dorsa DM. Endocrinology 2001;142:2336-2342. [PubMed: 11356680]

33. Chiellini G, Nguyen NH, Yoshihara HAI, Scanlan TS. Bioorg Med Chem Lett 2000;10:2607-2611. [PubMed: 11128634]

34. Chiellini G, Apriletti JW, al Yoshihara H, Baxter JD, Ribeiro RC, Scanlan TS. Chem Biol 1998;5:299_ 306. [PubMed: 9653548]

35. Gee AC, Carlson KE, Martini PGV, Katzenellenbogen BS, Katzenellenbogen JA. Mol Endocrinol 1999;13:1912-1923. [PubMed: 10551784]

36. Szapary D, Huang Y, Simons SS Jr. Mol Endocrinol 1999;13:2108-2121. [PubMed: 10598585]

37. Schneekloth JS, Fonseca FN, Koldobskiy M, Mandal A, Deshaies R, Sakamoto K, Crews CM. J Am Chem Soc 2004;126:3748-3754. [PubMed: 15038727]

$J$ Am Chem Soc. Author manuscript; available in PMC 2008 August 13. 

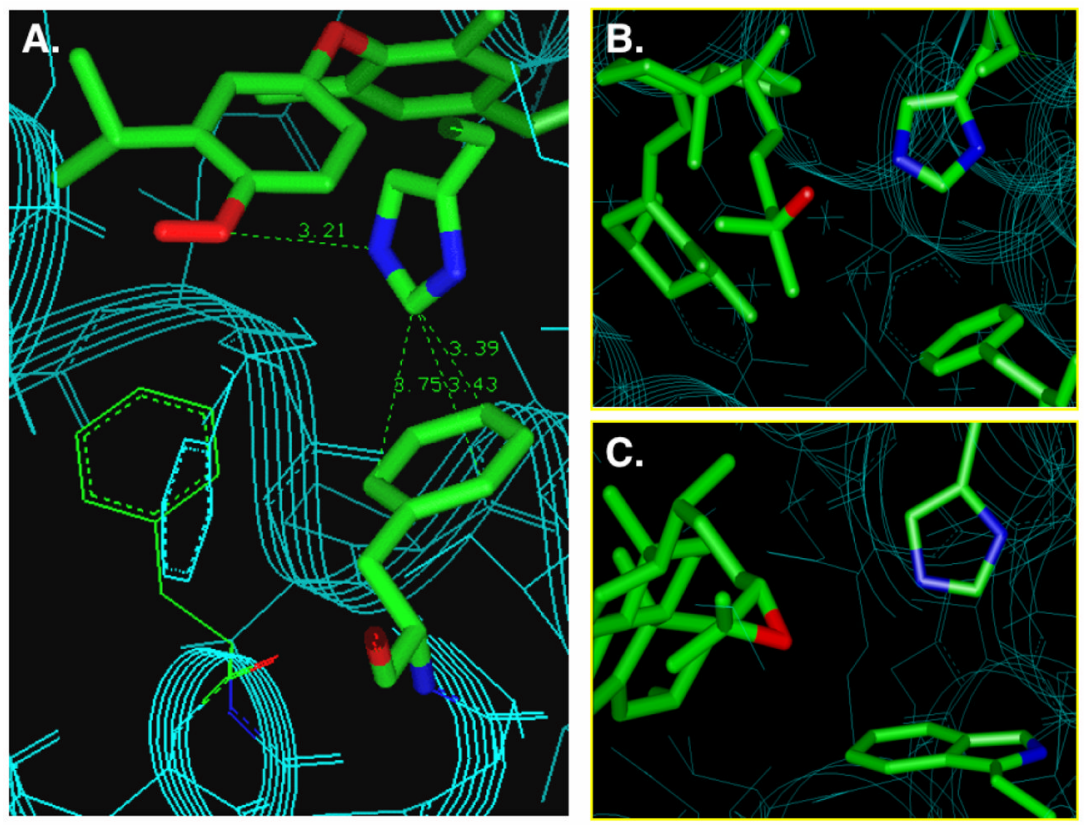

Figure 1.

The His-Trp and His-Phe switch serves as a transducer to relay ligand binding information to the AF-2 domain of nuclear receptors. a. TR $\alpha,{ }^{13} \mathrm{~b} . \mathrm{VDR},{ }^{12}$ and c. LXR. ${ }^{17}$ 

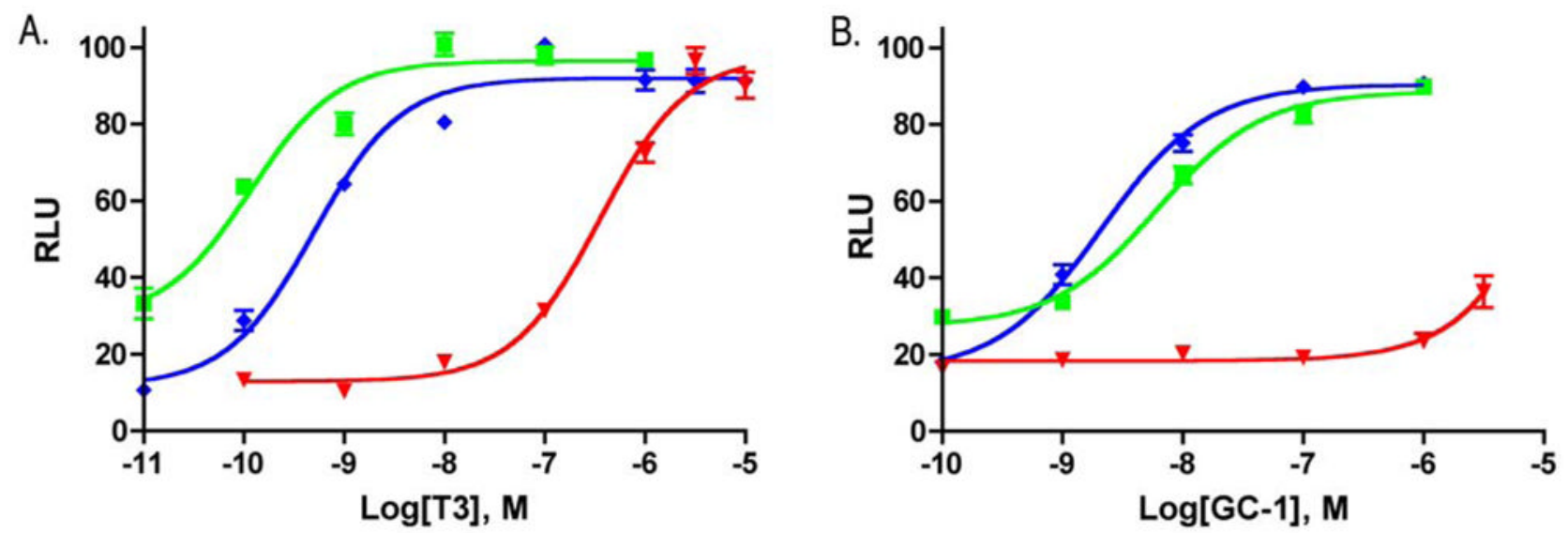

Figure 2.

Cellular dose response behavior of $\square \mathrm{TR} \alpha(\mathrm{wt}),-\mathrm{TR} \beta(\mathrm{wt})$ and $\tau \mathrm{TR} \beta(\mathrm{H} 435 \mathrm{~A})$ towards A. T3 and B. GC-1. 


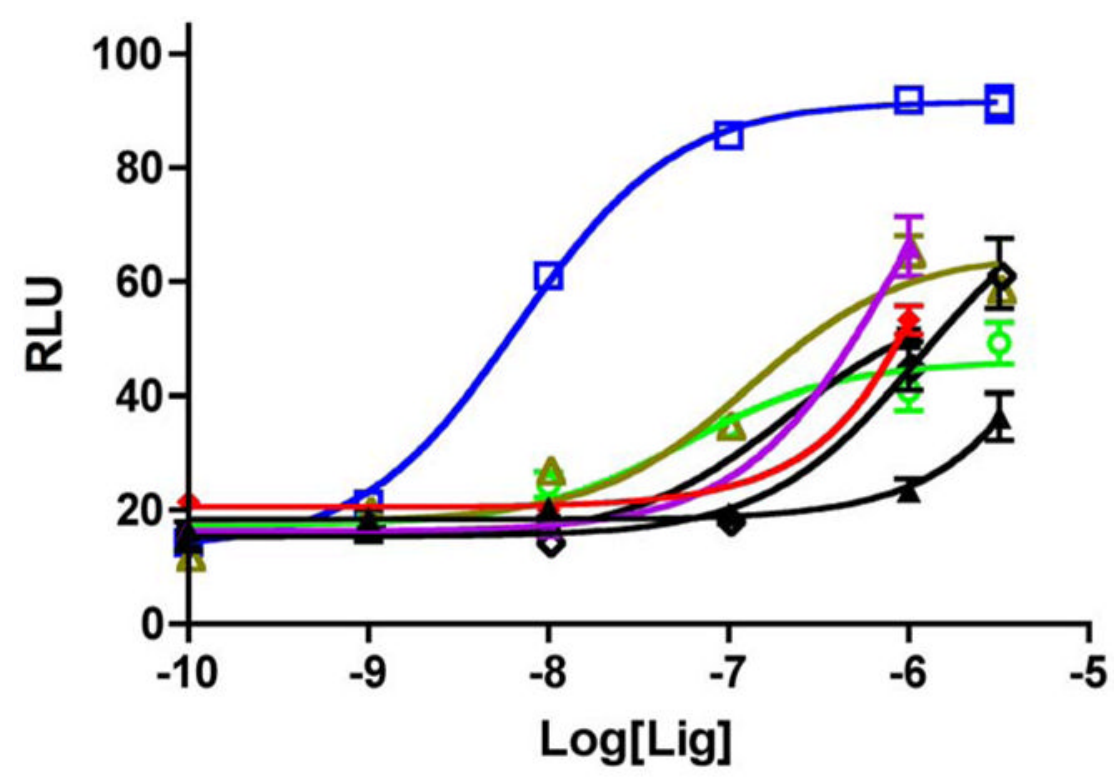

$\mathrm{QH} 2$

- $\mathrm{QH} 3$

$\triangle \mathrm{QH1}$

- QH4

- $\mathrm{QH} 7$

- QH5

- QH6

- $\mathrm{GC}-1$

Figure 3.

Cellular response of synthetic ligands towards TR $\beta(H 435 \mathrm{~A})$. 

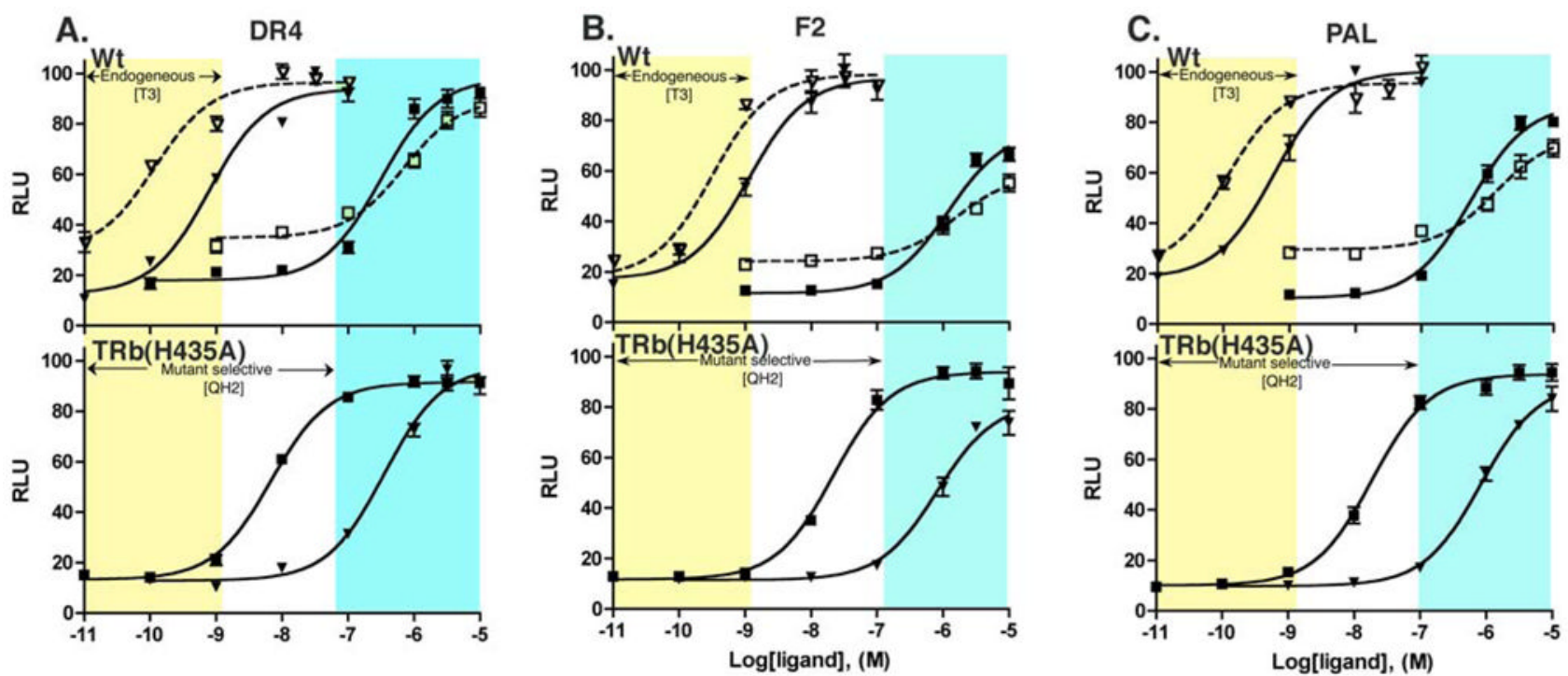

Figure 4.

Comparative dose response behavior of $\mathrm{QH} 2$ with $\mathrm{TR} \alpha(\mathrm{wt}), \mathrm{TR} \beta(\mathrm{wt})$ and $\mathrm{TR} \beta(\mathrm{H} 435 \mathrm{~A})$ on three consensus TRE reporters. $\nabla: \mathrm{TR} \alpha+\mathrm{T} 3, \circ: \mathrm{TR} \alpha+\mathrm{QH} 2, \tau$ : TR $\beta+\mathrm{T} 3, v: \mathrm{TR} \beta+\mathrm{QH} 2$. 


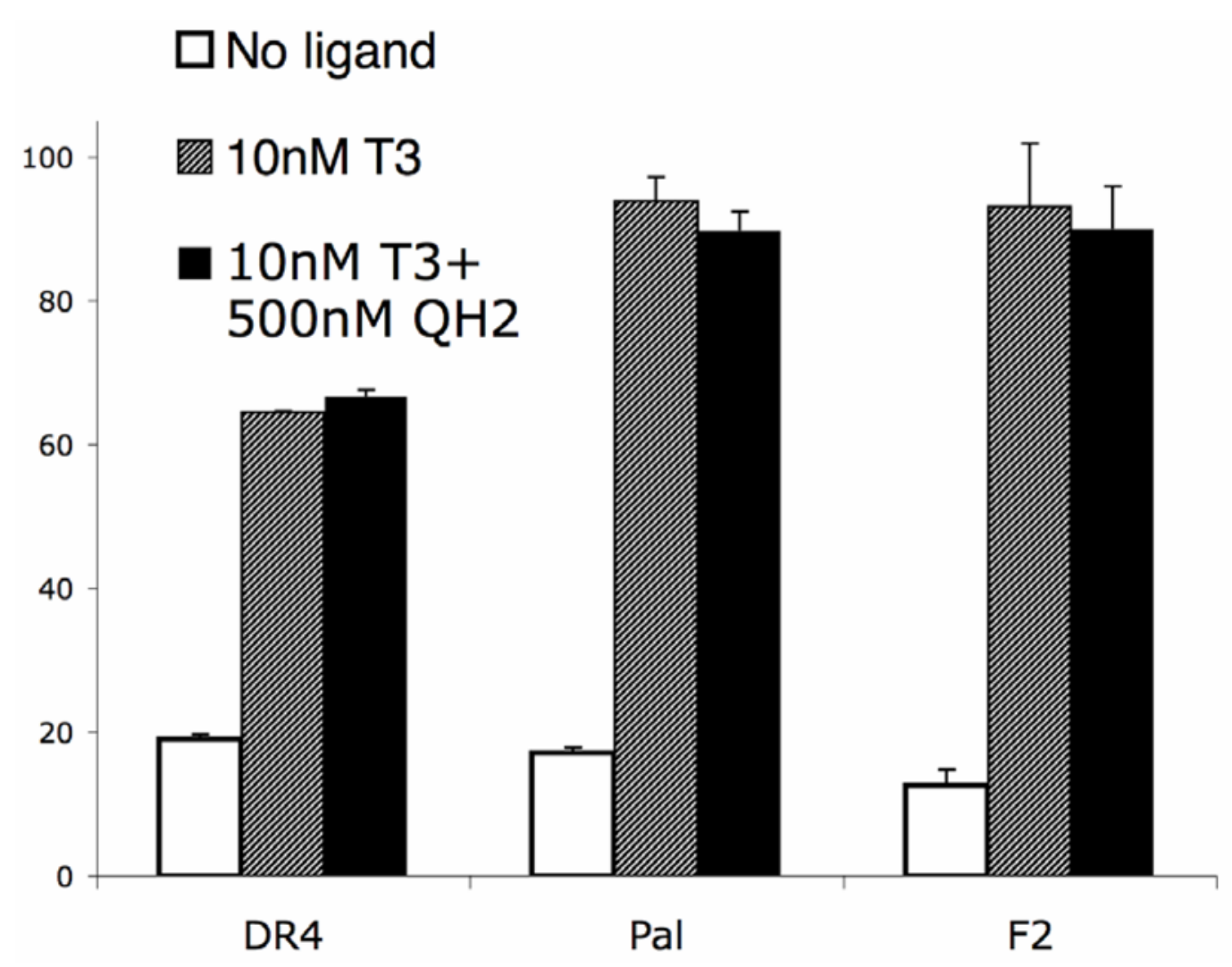

Figure 5.

Cellular response of T3 activated TR towards QH2. 
A.

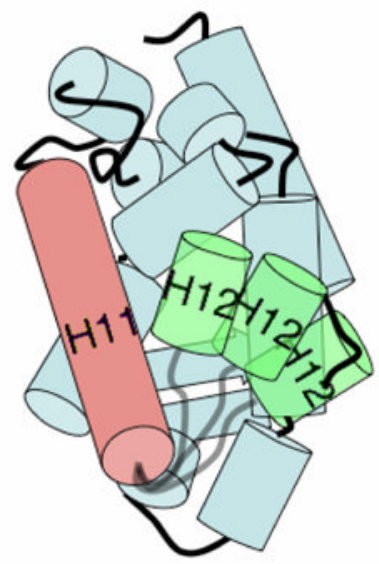

B.

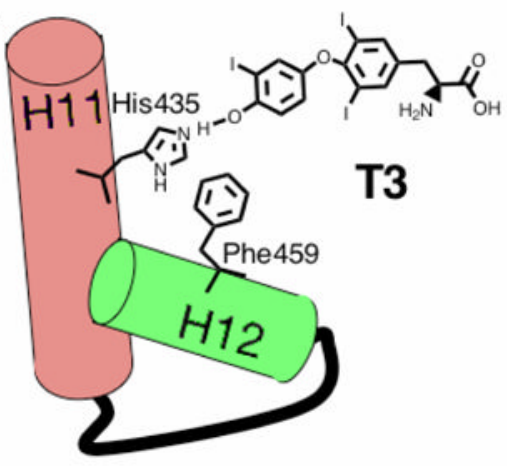

T3

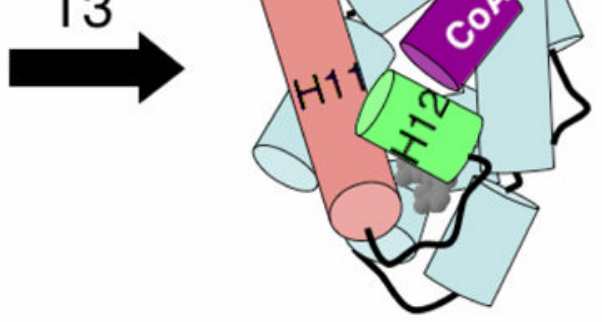

C.

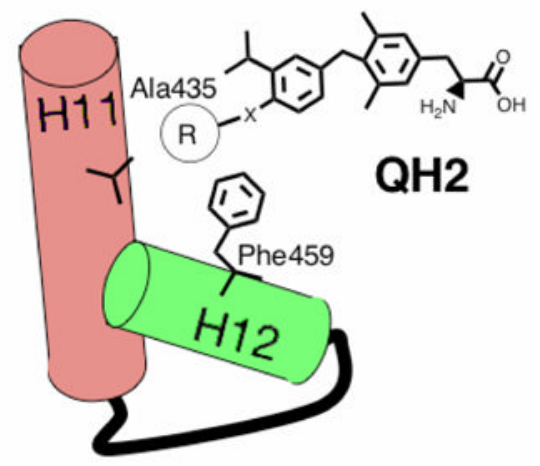

Scheme 1. Ligand-induced conformational change of nuclear receptors

A. Hormone binding repositions helix-12 (H12, green) to create a dimerization interface for transcriptional co-activators containing a conserved "LXXLL" NR-box (purple). B. In the HisPhe switch of TR $\beta$, T3 hydrogen bonds to His435, which interacts directly with Phe459 on helix-12. C. The transducer role of His435 may be replaced with appropriate hydrophobic groups. 
<smiles>[R2]c1ccc(Br)cc1C(C)[I-]</smiles>

$1 \mathrm{a} ; \mathrm{R}_{1}=\mathrm{Me}$

$1 \mathrm{~b} ; \mathrm{R}_{1}=\mathrm{Et}$

1c; $\mathrm{R}_{1}=\mathrm{n}-\mathrm{Pr}$<smiles>[R2]Oc1ccc(Cc2c(C)cc(OCC(=O)O)cc2C)cc1C(C)C</smiles>

b

$\begin{array}{ll}\text { 3a-c; }(\mathrm{X}=\mathrm{OH}, \mathrm{Y}=\mathrm{OBn}) & \text { QH1; } \mathrm{R}_{1}=\mathrm{Me} \\ \rightarrow \text { 4a-c; }(\mathrm{X}=\mathrm{H}, \mathrm{Y}=\mathrm{OH}) & \text { QH2; } \mathrm{R}_{1}=\mathrm{Et} \\ & \text { QH3; } \mathrm{R}_{1}=\mathrm{n}-\mathrm{Pr}\end{array}$

Scheme 2. Synthesis of alkoxy analogs

(a) n-BuLi, THF, $-78^{\circ} \mathrm{C}$ (b) $\mathrm{H}_{2}, 10 \% \mathrm{Pd} / \mathrm{C}, 9 \% \mathrm{AcOH} / \mathrm{EtOH}$ (c) $\mathrm{Cs}_{2} \mathrm{CO}_{3}, \mathrm{BrCH}_{2} \mathrm{CO}_{2} \mathrm{R}_{3}, \mathrm{DMF}$, then $\mathrm{NaOH}, \mathrm{MeOH}$. 
<smiles>Cc1cc(O[Na])cc(C)c1C=O</smiles>

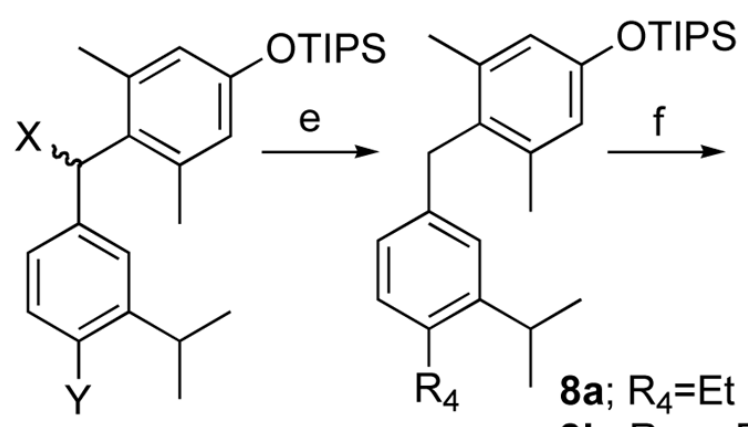

b

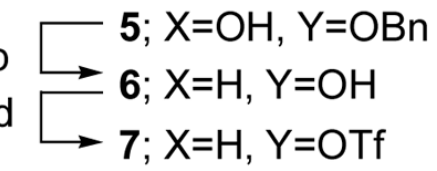

8b; $R_{4}=n-P r$

8c; $R_{4}=i-P r$

8d; $R_{4}=i-B u$

$8 \mathrm{e} ; \mathrm{R}_{4}=\mathrm{H}$<smiles>[R4]c1ccc(Cc2c(C)cc(O)cc2C)cc1C(C)C</smiles>

Scheme 3. Synthesis of alkyl substituted analogs a) n-BuLi, THF, $-78^{\circ} \mathrm{C}$ (b) $\mathrm{H}_{2}, 10 \% \mathrm{Pd} / \mathrm{C}, 9 \% \mathrm{AcOH} / \mathrm{EtOH}$ (c) $\mathrm{Cs}_{2} \mathrm{CO}_{3}, \mathrm{BrCH}_{2} \mathrm{CO}_{2} \mathrm{R}_{3}, \mathrm{DMF}$, then $\mathrm{NaOH}, \mathrm{MeOH}$ (d) $\mathrm{K}_{2} \mathrm{CO}_{3}$, DMF, p-NO $\mathrm{NhOTf}_{2}$ (e) $\mathrm{PdCl}_{2}$ (dppf), $\mathrm{R}_{4} \mathrm{MgCl}$ (f) TBAF, THF. 


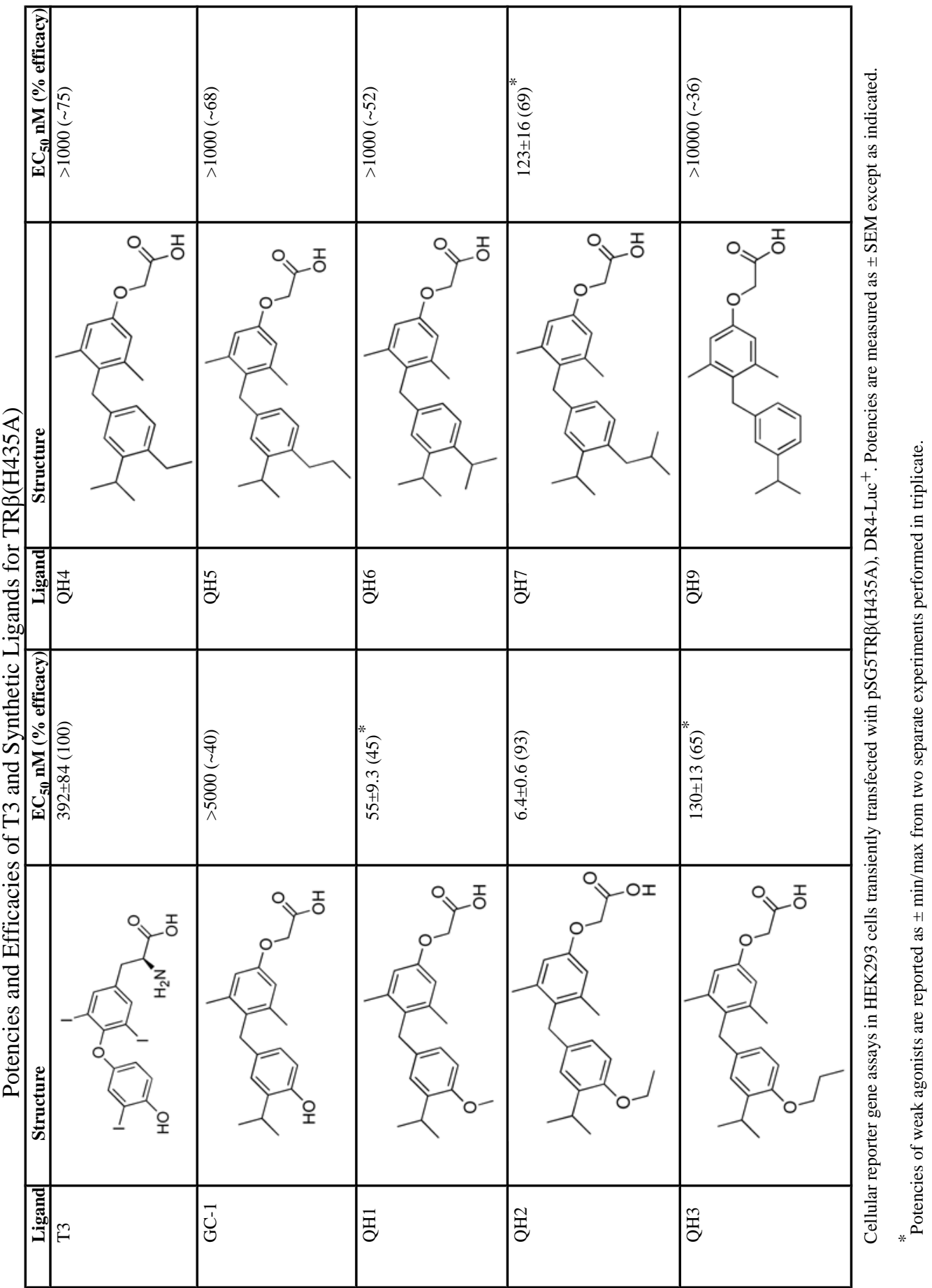

$J$ Am Chem Soc. Author manuscript; available in PMC 2008 August 13. 
Table 2

Summary of activities on three consensus promotors.

\begin{tabular}{lllll}
\hline TRE & Receptor & T3, nM (\% efficacy) & QH2, nM (\% efficacy) & GC-1, nM (\% efficacy) \\
\hline DR4 & TR $\alpha$ & $0.12 \pm 0.03(100)$ & $737 \pm 59.0(90)$ & $6.2 \pm 1.6(88)$ \\
& TR $\beta$ & $0.51 \pm 0.05(100)$ & $341 \pm 25(98)$ & $2.1 \pm 0.9(90)$ \\
& TR $\beta(H 435 A)$ & $392 \pm 84(97)$ & $6.43 \pm 0.57(93)$ & $>5000(40)$ \\
\hline F2 & TR $\alpha$ & $0.25 \pm 0.08(100)$ & $1596 \pm 84(76)$ & n.d. \\
& TR $\beta$ & $0.86 \pm 0.11(100)$ & $1240 \pm 122(58)$ & n.d. \\
& TR $\beta(H 435 A)$ & $774 \pm 53(82)$ & $27.9 \pm 7.1(93)$ & n.d. \\
\hline Pal & TR $\alpha$ & $0.12 \pm 0.04(100)$ & $1439 \pm 142(75)$ & n.d. \\
& $\operatorname{TR} \beta$ & $0.44 \pm 0.05(100)$ & $22.9 \pm 5.9(93)$ & n.d. \\
\hline
\end{tabular}

$\%$ efficacy: maximum inducible activity compared to TR(wt) with T3. n.d.: not determined 